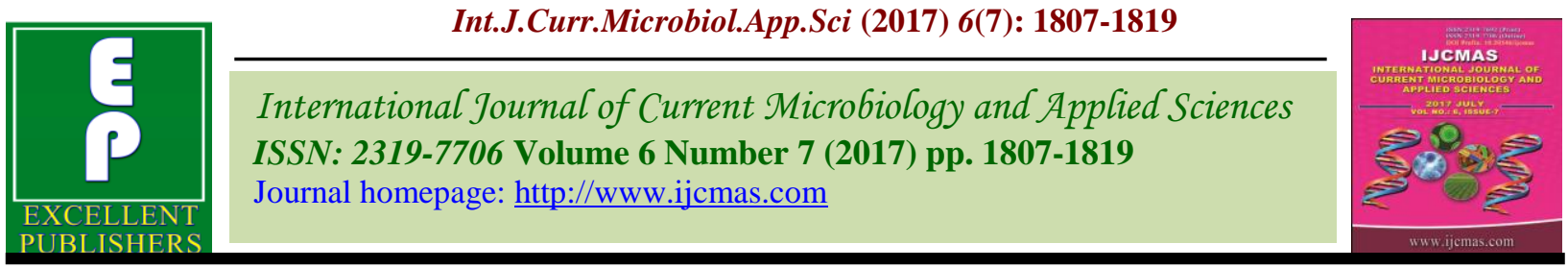

Original Research Article

https://doi.org/10.20546/ijcmas.2017.607.218

\title{
Half Diallel Analysis in Cowpea [Vigna unguiculata (L.)Walp.]
}

\author{
D.M. Raut*, A.B. Tamnar, S.V. Burungale and P.L. Badhe \\ Department of Agricultural Botany, College of Agriculture, Dhule-424 001, India \\ *Corresponding author
}

\section{A B S T R A C T}

The present investigation entitled "Diallel Analysis in Cowpea (Vignaunguiculata (L.) Walp.)" was conducted during kharif, 2013. The present study involves seven parents which were crossed in half diallel fashion in order to determine heterosis and combining ability. Seven parents viz., GC-3, CPD-91, HC-08-02, PGCP-1, GC-06-01, JOB-129 and CP-105, their resultant 21 crosses along with two standard checks viz., VCM-8 and Phule Pandhari were grown during Kharif 2013 in a Randomized Block Design with two replications. Seven diverse cowpea parents were selected and crossed in half diallel

\begin{tabular}{|l|}
\hline Ke y w or d s \\
Half diallel, \\
gca, sca, \\
Yield component. \\
\hline Article Info \\
\hline $\begin{array}{l}\text { Accepted: } \\
\text { 19 June } 2017 \\
\text { Available Online: } \\
10 \text { July } 2017\end{array}$ \\
\hline \hline
\end{tabular}
fashion in order to determine combining ability to identify promising hybrids for eleven traits including yield and its components. Analysis of variance for general and specific combining ability revealed that gca and sca variances were significant for all the characters. Whereas, comparison of $\sigma^{2}$ gca/ $\sigma^{2}$ sca indicated the non additive gene effects were predominance for all the characters except days to maturity, number of pod per plant and protein content. Among the parents $\mathrm{CP}-105$ was proved to be a good general combiner for six characters viz., days to $50 \%$ flowering, days to maturity, number of branches per plant, number of pods per plant, seed yield per plant and protein content and GC-3 showed best gca effect for number of branches per plant, number of pods per plant, number of seed per pod, seed yield per plant and harvest index. While, JOB-129 was good general combiner for days to $50 \%$ flowering, days to maturity, 100 seed weight and protein content. Among the crosses GC-3 x HC-08-02 was best specific combination for seed yield per plant as well as number of pods per plant, number of branches per plant, 100 seed weight, harvest index and protein content. It is evident from present investigation that the hybrid combinations GC-3 x HC-08-02, GC-06-01 x JOB- 129, HC-08-02 x PGCP-1 and GC-3 x CP-105 exhibited the high per se performance and sca effect for seed yield per plant and highly promising even in respect of other characters could be advanced by selecting desirable segregants and recombinants in each generation for funneling the new genotype or for using further advanced breeding programme.

\section{Introduction}

Cowpea [Vigna unguiculata (L.) Walp.] is called as poor man's food or vegetable meat due to high amount of protein in grain with better biological value on dry weight basis. Cowpea grain contains about $24.8 \%$ protein, $1.9 \%$ fat and $63.6 \%$ carbohydrates and is rich source of calcium and iron (Davis et al.,

2000). In the cultigens cowpea, four sub species have been identified, in which unguiculata, the grain types and sesquipedal is the yard long bean type were commonly cultivated. The most encountered problem with cultivation of yard long bean or vegetable type is providing space and support 
for its vigorous viny growth habit (Valarmathi et al., 2007). In view of low input requirement and short maturity, its cultivation is quite economic. As compared with crops particularly the cereals, cowpea offers better chances of crop production under adverse conditions of moisture stress and low fertility. Though India is leading producers of cowpea, however, its grain productivity is dismally low. In cowpea, research work for its improvement is very limited. Therefore, there is a great scope forits improvement and to increase the production by developing high yielding, disease and pest resistant, moisture stress resistant varieties (Ehlers and Hall, 1997) and improvement in nutritional value by increasing especially protein content. Among the different pulses grown, cowpea is grown in 12.5 million hectares with the productivity of $499 \mathrm{~kg}$ per ha in India (Anonymous, 2012).

A breeder is confronted at the onset, by a rather complex problem normally the choice of parents for hybridization, because yield is a complex character, comprising a number of components each of which is a polygenically controlled and therefore, very susceptible to environmental fluctuations. The choice becomes still more difficult when the breeder has to select the parents from large germplasm and become often difficult to predict the parents on per se performance whether, any two parents would combine well to produce desirable genotypes. What is more important than characteristics of the individual parents is how well they combine with each other. The information concerning breeding behavior of the parents is of fundamental important in plant breeding programme. For this application of biometric technique like diallel analysis was appeared to be the best useful tool for screening parents with rapid and reasonable degree of confidence which has practical utility in breeding programme aimed at genetic improvement of yield. Sprague and Tatum (1942) suggested that the breeding value of genotypes, including combining ability helps in the identification of parents with high gca and parental combinations with high sca. Based on combining ability analysis of different characters, higher sca values refers to dominance gene effects and higher gca effects indicate a greater role of additive gene effects controlling these characters. But both the gca and sca values are not significant then epistatic gene effects may play an important role in determining these characters. At present frequently diallel or line $\mathrm{x}$ tester analysis is applied (Marciniak et al., 2003; Ahuja and Dhayal, 2007). The knowledge on nature and magnitude of gene effects controlling partitioned into genetic components attributed to general combining ability (gca) variances and specific combining ability (sca) variances and effects were analyzed by adopting Model-I, Method-II of Griffing's (1956), assumes the following mathematical model.

$\mathrm{X} i \mathrm{j}=\mu+\mathrm{gi}+\mathrm{gj}+\mathrm{sij}+1 / \mathrm{bc} \Sigma$

Eeijkl Where,

$\mathrm{i}, \mathrm{j}=1,2, \ldots \ldots \ldots, \mathrm{n}$

$\mathrm{k}=1,2, \ldots \ldots \ldots, \mathrm{b}$

$1=1,2, \ldots \ldots \ldots ., \mathrm{c}$

$\mu=$ Population mean

$\mathrm{gi}=$ General combining ability (gca) effect of $i^{\text {th }}$ parent inheritance of characters related to yield and its component traits will be helpful in formulating efficient breeding programme and enhancing the of $\mathrm{j}^{\text {th }} \mathrm{gj}=$ General combining ability (gca) effect parent 
Sij= Specific combining ability (sca) effect yield of the crops as well as finding out good general and specific combiners for yield and yield component traits. Therefore, the present investigation was planned to investigate the combining ability for yield and yield contributing traits.

\section{Materials and Methods}

There are seven genotypes namely GC-3, CPD-91, JOB-129, HC-08-02, CPD-91, PGCP-1, and GC-06- 01 were selected based on the phenotypic diversity of the plants in respect of yield and yield components. Crosses were made between the seven parents following the scheme of $7 \times 7$ half diallel and 21 hybrids were obtained. All these crosses along with parents were grown together during Kharif 2013 in a Randomized Block Design (RBD) with two replications at Agricultural Botany Section, College of Agriculture, Dhule, Maharashtra, India. The row of $4.5 \mathrm{~m}$. length and spacing of $0.45 \mathrm{~m}$ was adopted. Border rows were planted at the extreme of each replication. All the recommended cultural practices were carried out to raise a good crop. Five competitive plants were selected randomly for recording the data on yield and its contributing traits viz., days to $50 \%$ flowering, days to maturity, plant height at maturity, number of branches per plant, number of pods per plant, pod length $(\mathrm{cm})$, number of seeds per plant, 100 seed weight $(\mathrm{g})$, seed yield per plant $(\mathrm{g})$, harvest index $(\%)$ and protein content $(\%)$. The mean data of each plot was used for statistical analysis. The variation among the hybrids was of $(\mathrm{i} \times \mathrm{j})^{\text {th }}$ cross eijkl= Environmental effect associated with the $\mathrm{ijk}^{\text {th }}$ individual observation $\mathrm{n}=$ Number of parents,

$\mathrm{b}=$ Number of replications

$\mathrm{c}=$ Number of individual in each replication The model assumes that
$\mathrm{a}=\Sigma \mathrm{gij}=0$ and $\Sigma \mathrm{S}_{\mathrm{ij}}=0$ (for

each i)

$\mathrm{b}=$ the error (eijkl) is normally and independently distributed with mean equal to zero and variance equals $\sigma^{2} \mathrm{c}$.

\section{Results and Discussion}

Analysis of variance revealed significant differences among the genotypes, parents and hybrids for all characters except pod length in parents (Table 1). This may obviously be attributed to the existence of sufficient variation among the parents and hybrids. Average performance of hybrids was different from that of the parent for all characters except pod length, as evident from the significant parent's vs. crosses source of variation for the characters studied. These results were in consonance with that of Meena et al., (2009) for seed yield per plant and other related traits. Analysis for combining ability of variances due to general and specific combining ability was significant for all the characters studied (Tables 2 and 3) indicating the presence of adequate amount of variability and there is possibility of selection of desirable plants for trait of interest. A wide range of variation was observed $\sigma^{2}$ gca for most of the characters studied (Table 4). Variances due to general combining ability were higher as compared to specific combining ability for all the characters except pod length. The maximum GCA was recorded for plant height at maturity and protein content while minimum for pod length. The ratios of general combining ability variances were high for the characters days to maturity, number of pods per plant and protein content (Table 4). Further, it revealed that both the additive and non-additive gene effects are important in inheritance all characters. The comparison of magnitude of general combining ability and specific combining ability variance indicated that the nonadditive genetic effects were predominant in 
the characters, days to $50 \%$ flowering, plant height, number of branches per plant, pod length, number of seeds per pod, 100 seed weight, seed yield per plant and harvest index which suggested prime role of non-additive gene action. These results are in accordance with Ushakumari et al., (2010), Kadam et al., (2013)and Chaudhari et al., (2013) revealed that magnitude of general combining ability (gca) variances were smaller than the specific combining ability (sca) variances for pods per plant, seeds per pod and 100 seed weight. The additive genetic effects were predominant for control of the characters, days to maturity, number of pods per plant and protein content suggesting influenced by additive gene action, also confirmed by $\sigma^{2}$ gca $/ \sigma^{2}$ scaratio which was more than unity. The present results are in corroboration with the findings of Patel et al., (2013). The predominant role of additive gene action in the inheritance of protein content was also reported by Mannivannan and Sekar (2005) and Chaudhari et al., (2013). Under the circumstances, where both additive and non-additive gene actions were in operation, the most appropriate and effective breeding approach would be to mop up the additive genes and simultaneously maintaining degree of heterozygosity for exploiting dominance component by adopting biparental mating and inter se crossing between suitable lines followed by recurrent selection. Potentiality of parent to be used in hybridization or of cross used for commercial hybrid may be determined by comparing the per se performance of the parent, the $\mathrm{F} 1$ value and the combining ability effects.

The parents showed significant high general combining ability for eleven characters presented in table 5. From which it can concluded that none of the parent reported uniformity in high general combining ability for all the characters. The parent CP-105 exhibited highly significant gca for characters, seed yield per plant, days to $50 \%$ flowering, days to maturity, number of branches per plant, number of pods per plant, and protein content and GC-3 for seed yield per plant, number of branches per plant, number of pods per plant, number of seeds per plant, and harvest index. JOB-129 for four characters, days to $50 \%$ flowering, days to maturity, 100 seed weight and protein content. While, CPD-91for days to $50 \%$ flowering, days to maturity and plant height at maturity and GC-06-01 for three characters days to $50 \%$ flowering, pod length and protein content. The parents $\mathrm{HC}$ 08-02 andPGCP-1 recorded highly significant gca for each two characters viz., Plant height at maturity, number of branches per plant and pod length, 100 seed weight, respectively.

Considering the gca performance (Table 5) it could be concluded that the parent showing significant high or average gca effects were also having higher or average mean value for respective characters. For instance parent GC-3 exhibited positive and significant gca effect and have high mean value for seed yield per plant, number of branches per plant, number of pods per plant, number of seeds per pod and harvest index. Similarly, superior parent CP-105 was good general combiner for seed yield per plant have higher per se performance for days to $50 \%$ flowering, days to maturity, number of branches per plant, number of pods per plant and protein content. Similar results were also reported by Patil and Bhapkar (1986) and Ayo-vaughan et al., (2013). GC-3 was best general combiner for seed yield per plant, seeds per pod and pods per plant confirmed earlier in the report of Kumar and Sangawan (2005). 
Table.1 Analysis of variance for diallel analysis for seed yield and its components traits in cowpea

\begin{tabular}{|c|c|c|c|c|c|c|c|c|c|c|c|c|}
\hline \multirow{3}{*}{$\begin{array}{r}\text { Source of } \\
\text { Variation }\end{array}$} & \multirow{3}{*}{ d.f. } & \multicolumn{11}{|c|}{ Mean sum of squares } \\
\hline & & Days to $50 \%$ & Days to & Plant Height & No. of & No. ofPods/ & $\begin{array}{l}\text { No. } \\
\text { of }\end{array}$ & $\begin{array}{l}100 \\
\text { Seed }\end{array}$ & $\begin{array}{l}\text { SeedYiel } \\
\text { d }\end{array}$ & Harvest & Protein & \\
\hline & & Flowering & Maturity & at Maturity & $\begin{array}{c}\text { Branches } \\
\text { /Plant }\end{array}$ & Plant & Length & Seeds/ Pod & Weight & /Plant & Index & Contain \\
\hline Replications & 1 & 1.446 & 1.786 & 12.635 & 0.483 & 0.206 & 1.612 & 0.339 & 0.031 & 5.375 & 6.365 & 0.845 \\
\hline Treatments & 27 & $60.632 * *$ & $121.587 * *$ & $344.025 * *$ & $0.991 * *$ & $21.493 * *$ & $2.643 * *$ & $3.914 * *$ & $2.938 * *$ & $13.851 * *$ & $5.771 * *$ & $118.897 * *$ \\
\hline Parents & 6 & $62.333 * *$ & $190.643 * *$ & $581.913 * *$ & $1.190 * *$ & $26.025 * *$ & 1.073 & $1.617^{*}$ & $4.693 * *$ & $4.947 *$ & $4.298 * *$ & $230.834 * *$ \\
\hline Crosses & 20 & $59.745 * *$ & $100.431 * *$ & $287.018^{* *}$ & $0.889 * *$ & $18.997 * *$ & $3.149 * *$ & $4.553 * *$ & $2.459 * *$ & $13.124 * *$ & $4.831 * *$ & $89.631 * *$ \\
\hline $\begin{array}{l}\text { Parent vs } \\
\text { Crosses }\end{array}$ & 1 & $68.149 * *$ & $130.381 * *$ & $56.840 * *$ & $1.844 * *$ & $44.229 * *$ & 1.929 & $4.923 * *$ & $1.972^{*}$ & $81.831 * *$ & $33.411 * *$ & $32.595 * *$ \\
\hline
\end{tabular}


Table.2 Estimates of General Combining ability effects for seed yield and its components traits in cowpea

\begin{tabular}{|c|c|c|c|c|c|c|c|c|c|c|c|}
\hline Parents & $\begin{array}{c}\text { Days to } 50 \% \\
\text { Flowering }\end{array}$ & $\begin{array}{l}\text { Days to } \\
\text { Maturity }\end{array}$ & $\begin{array}{l}\text { Plant Height } \\
\text { at Maturity }\end{array}$ & $\begin{array}{c}\text { No. of } \\
\text { Branches } \\
\text { /Plant }\end{array}$ & $\begin{array}{l}\text { No. of Pods/ } \\
\text { Plant }\end{array}$ & Pod Length & $\begin{array}{c}\text { No. of Seeds/ } \\
\text { Pod }\end{array}$ & $\begin{array}{l}100 \text { Seed } \\
\text { Weight }\end{array}$ & $\begin{array}{l}\text { Seed Yield } \\
\text { /Plant }\end{array}$ & $\begin{array}{l}\text { Harvest } \\
\text { Index }\end{array}$ & $\begin{array}{l}\text { Protein } \\
\text { Contain }\end{array}$ \\
\hline $\mathrm{GC}-3$ & $2.579 * *$ & $3.651 * *$ & 0.658 & $0.263^{* *}$ & $3.317 * *$ & 0.070 & $0.568 * *$ & 0.177 & $2.206 * *$ & $1.601 * *$ & $-2.638 * *$ \\
\hline CPD-91 & $-2.032 * *$ & $-4.849 * *$ & $1.755 * *$ & -0.137 & $-1.394 * *$ & -0.170 & -0.287 & 0.250 & -0.063 & -0.152 & $-4.511 * *$ \\
\hline HC-08-02 & $1.357 * *$ & $5.762 * *$ & $13.882 * *$ & $0.586^{* *}$ & $-1.016^{*}$ & -0.045 & 0.164 & $-0.718 * *$ & $-0.990 * *$ & $-0.747 * *$ & $-5.719 * *$ \\
\hline PGCP-1 & $2.635 * *$ & $3.429 * *$ & $-7.806^{* *}$ & $-0.359 * *$ & $-1.371 * *$ & $0.390 *$ & 0.249 & $0.849 * *$ & $-0.710^{*}$ & -0.159 & $-2.139 * *$ \\
\hline GC-06-01 & $-1.143 * *$ & $2.040 * *$ & $-1.522 * *$ & $-0.492 * *$ & $-1.116^{*}$ & $0.472 *$ & 0.271 & -0.062 & $-0.800 * *$ & -0.279 & $3.075 * *$ \\
\hline JOB-129 & $-1.698 * *$ & $-5.016^{* *}$ & $-7.292 * *$ & $-0.192^{*}$ & -0.627 & $-0.407 *$ & $-0.855^{* *}$ & $0.535^{* *} *$ & -0.446 & -0.092 & $5.810 * *$ \\
\hline CP-105 & $-1.698 * *$ & $-5.016^{* *}$ & 0.324 & $0.330 * *$ & $2.206 * *$ & -0.311 & -0.110 & $-1.030 * *$ & $0.801 * *$ & -0.173 & $6.121 * *$ \\
\hline
\end{tabular}


Table.3 Estimates of specific combining ability effects for seed yield and its components traits in cowpea

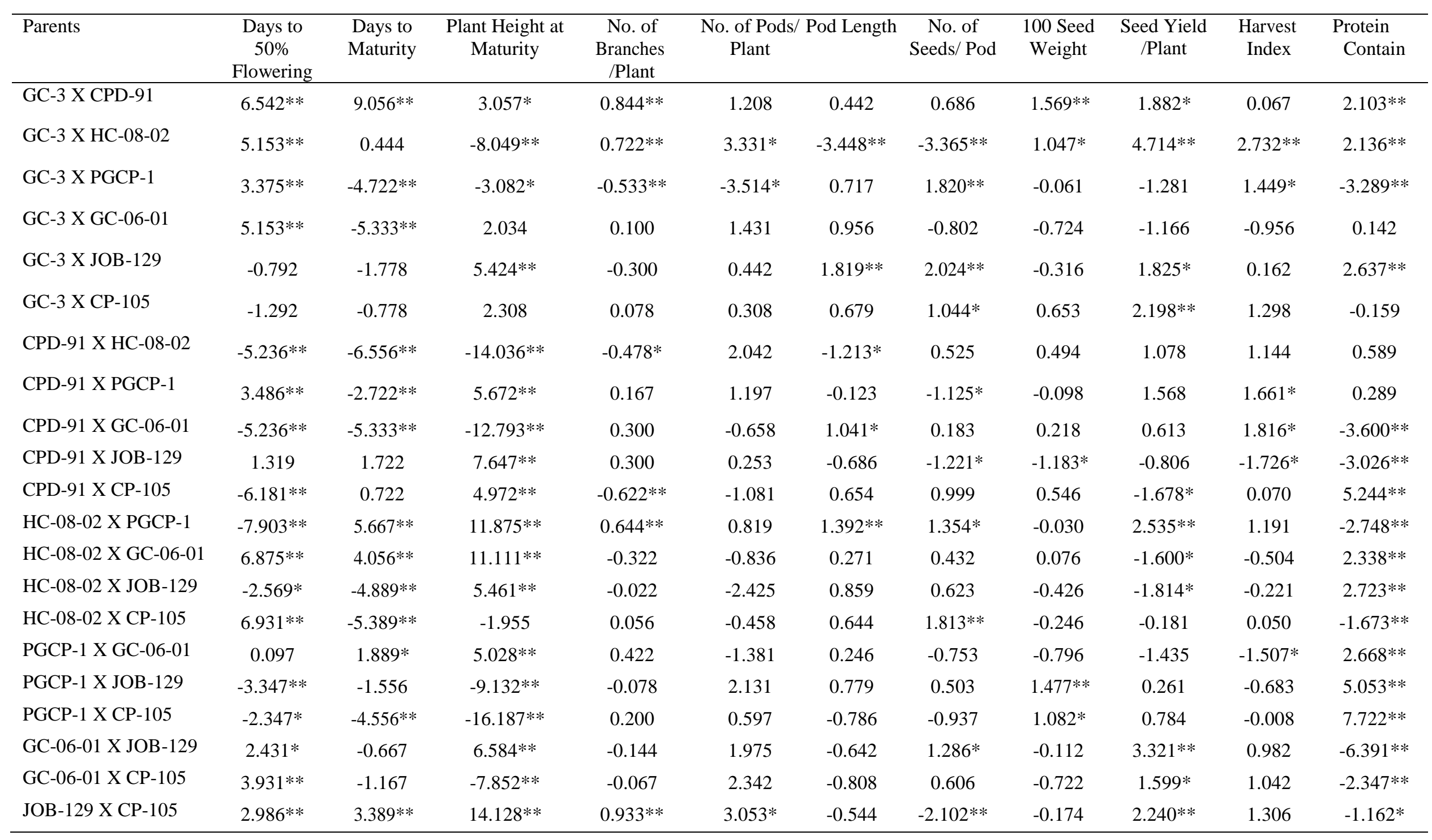

* Significant at 5\%level. $\quad * * \quad$ Significant at $1 \%$ level. 
Table.4 Analysis of variance for combining ability for seed yield and its components traits in cowpea

\begin{tabular}{|c|c|c|c|c|c|c|c|c|c|c|c|c|}
\hline \multirow{2}{*}{\multicolumn{2}{|c|}{$\begin{array}{l}\text { Source of d.f. } \\
\text { Variation }\end{array}$}} & \multicolumn{11}{|c|}{ Mean sum of squares } \\
\hline & & $\begin{array}{c}\text { Days to } \\
50 \% \\
\text { Flowering }\end{array}$ & $\begin{array}{l}\text { Days to } \\
\text { Maturity }\end{array}$ & $\begin{array}{l}\text { Plant } \\
\text { Heightat } \\
\text { Maturity }\end{array}$ & $\begin{array}{l}\text { No. of } \\
\text { Branches } \\
\text { /Plant }\end{array}$ & $\begin{array}{l}\text { No. of } \\
\text { Pods/ } \\
\text { Plant }\end{array}$ & $\begin{array}{c}\text { Pod } \\
\text { Length }\end{array}$ & $\begin{array}{l}\text { No. of } \\
\text { Seeds/ } \\
\text { Pod }\end{array}$ & $\begin{array}{l}100 \text { Seed } \\
\text { Weight }\end{array}$ & $\begin{array}{l}\text { Seed Yield } \\
\text { /Plant }\end{array}$ & $\begin{array}{l}\text { Harvest } \\
\text { Index }\end{array}$ & $\begin{array}{l}\text { Protein } \\
\text { Contain }\end{array}$ \\
\hline G.C.A. & 6 & $39.962 * *$ & $204.414 * *$ & $469.107 * *$ & $1.422 * *$ & $33.550 * *$ & $1.010^{*}$ & $1.967 * *$ & $4.021 * *$ & $11.749 * *$ & $4.926 * *$ & $217.905 * *$ \\
\hline S.C.A. & 21 & $27.560 * *$ & $19.759 * *$ & $87.128 * *$ & $0.231 * *$ & $4.231 *$ & $1.410 * *$ & $1.954 * *$ & $0.740 * *$ & $5.548 * *$ & $2.303 * *$ & $14.175 * *$ \\
\hline Error & 27 & 1.242 & 1.004 & 2.149 & 0.056 & 2.034 & 0.309 & 0.300 & 0.212 & 0.737 & 0.550 & 0.295 \\
\hline \multicolumn{13}{|c|}{ Components of variance } \\
\hline \multicolumn{2}{|c|}{$\begin{array}{l}\text { Source of } \\
\text { Variation }\end{array}$} & $\begin{array}{c}\text { Days to } \\
50 \% \\
\text { Flowering }\end{array}$ & $\begin{array}{l}\text { Days to } \\
\text { Maturity }\end{array}$ & $\begin{array}{l}\text { Plant Height } \\
\text { at Maturity }\end{array}$ & $\begin{array}{c}\text { No. of } \\
\text { Branches } \\
\text { /Plant }\end{array}$ & $\begin{array}{l}\text { No. of } \\
\text { Pods/ } \\
\text { Plant }\end{array}$ & $\begin{array}{c}\text { Pod } \\
\text { Length }\end{array}$ & $\begin{array}{l}\text { No. of } \\
\text { Seeds/ } \\
\text { Pod }\end{array}$ & $\begin{array}{l}100 \text { Seed } \\
\text { Weight }\end{array}$ & $\begin{array}{l}\text { Seed Yield } \\
\text { /Plant }\end{array}$ & $\begin{array}{c}\text { Harvest } \\
\text { Index }\end{array}$ & $\begin{array}{l}\text { Protein } \\
\text { Contain }\end{array}$ \\
\hline \multicolumn{2}{|c|}{$\sigma^{2}$ gca } & 4.302 & 22.601 & 51.884 & 0.152 & 3.502 & 0.078 & 0.185 & 0.423 & 1.224 & 0.486 & 24.179 \\
\hline \multicolumn{2}{|c|}{$\sigma^{2} \mathrm{sca}$} & 26.318 & 18.755 & 84.979 & 0.175 & 2.198 & 1.101 & 1.654 & 0.527 & 4.811 & 1.752 & 13.880 \\
\hline \multicolumn{2}{|c|}{$\sigma^{2}$ error } & 1.242 & 1.004 & 2.149 & 0.056 & 2.034 & 0.309 & 0.300 & 0.212 & 0.737 & 0.550 & 0.295 \\
\hline \multicolumn{2}{|c|}{$\sigma^{2}$ gca $\sigma^{2}$ sca } & 0.163 & 1.205 & 0.611 & 0.869 & 1.593 & 0.071 & 0.112 & 0.802 & 0.254 & 0.277 & 1.742 \\
\hline
\end{tabular}

*Significant at 5\%level. **Significant at $1 \%$ level.

$\sigma^{2}$ gca-General combining ability variance, $\sigma^{2}$ sca -Specific combining ability variance, $\sigma^{2}$ error -Environmental variance 
Table.5 Parents showing significant and high general combining ability for seed yield and its components traits in cowpea

\begin{tabular}{|c|c|c|c|}
\hline Parent & No. of characters & Per se performance & Name of the characters \\
\hline GC-3 & 5 & $\begin{array}{c}10.00 \\
4.00 \\
16.90 \\
11.59 \\
11.02\end{array}$ & $\begin{array}{l}\text { Seed yield per plant } \\
\text { Number of branches per plant } \\
\text { Number of pods per plant } \\
\text { Number of seeds per plant } \\
\text { Harvest index }\end{array}$ \\
\hline CPD-91 & 3 & $\begin{array}{l}48.00 \\
66.00 \\
74.26\end{array}$ & $\begin{array}{l}\text { Days to } 50 \% \text { flowering } \\
\text { Days to maturity } \\
\text { Plant height at maturity }\end{array}$ \\
\hline HC-08-02 & 2 & $\begin{array}{c}93.57 \\
4.80\end{array}$ & $\begin{array}{l}\text { Plant height at maturity } \\
\text { Number of branches per plant }\end{array}$ \\
\hline PGCP-1 & 2 & $\begin{array}{l}12.14 \\
10.83\end{array}$ & $\begin{array}{l}\text { Pod length } \\
100 \text { seed weight }\end{array}$ \\
\hline GC-06-01 & 3 & $\begin{array}{c}40.0 \\
12.88 \\
40.02\end{array}$ & $\begin{array}{l}\text { Days to } 50 \% \text { flowering } \\
\text { Pod length } \\
\text { Protein content }\end{array}$ \\
\hline JOB-129 & 4 & $\begin{array}{l}46.00 \\
66.00 \\
11.35 \\
41.98\end{array}$ & $\begin{array}{l}\text { Days to } 50 \% \text { flowering } \\
\text { Days to maturity } \\
100 \text { seed weight } \\
\text { Protein content }\end{array}$ \\
\hline CP-105 & 6 & $\begin{array}{c}8.79 \\
44.00 \\
68.00 \\
4.30 \\
13.90 \\
38.71\end{array}$ & $\begin{array}{l}\text { Seed yield per plant } \\
\text { Days to } 50 \% \text { flowering } \\
\text { Days to maturity } \\
\text { Number of branches per plant } \\
\text { Number of pods per plant } \\
\text { Protein content }\end{array}$ \\
\hline
\end{tabular}


Table.6 Best significant general combiners and specific combinations for seed yield and its components traits in cowpea

\begin{tabular}{|c|c|c|c|c|c|}
\hline Characters & $\begin{array}{l}\text { Best general } \\
\text { combiner }\end{array}$ & gca effects & $\begin{array}{l}\text { No. of crosses with } \\
\text { significant sca effects }\end{array}$ & $\begin{array}{l}\text { Best specific combination with high sca } \\
\text { effects }\end{array}$ & sca effect \\
\hline Days to $50 \%$ flowering & $\begin{array}{l}\text { CPD-91 } \\
\text { CP-105 } \\
\text { JOB-129 } \\
\text { GC-06-01 }\end{array}$ & $\begin{array}{l}-2.032 \\
-1.698 \\
-1.698 \\
-1.143\end{array}$ & 7 & $\begin{array}{l}\text { HC-08-02 x PGCP-1 } \\
\text { CPD-91 x CP-105 } \\
\text { CPD-91 x HC-08-02 } \\
\text { CPD-91 x GC-06-01 } \\
\text { PGCP-1 x JOB-129 } \\
\text { HC-08-02 x JOB-129 } \\
\text { PGCP-1 x CP-105 }\end{array}$ & $\begin{array}{l}-7.903 \\
-6.181 \\
-5.236 \\
-5.236 \\
-3.347 \\
-2.569 \\
-2.347\end{array}$ \\
\hline Days to maturity & $\begin{array}{l}\text { CP-105 } \\
\text { JOB-129 } \\
\text { CPD-91 }\end{array}$ & $\begin{array}{l}-5.016 \\
-5.016 \\
-4.849\end{array}$ & 8 & $\begin{array}{l}\text { CPD-91 x HC-08-02 } \\
\text { HC-08-02 x CP-105 } \\
\text { GC-3 x GC-06-01 } \\
\text { CPD-91 x GC-06-01 } \\
\text { HC-08-02 × JOB-129 } \\
\text { GC-3 x PGCP-1 } \\
\text { PGCP-1 x CP-105 } \\
\text { CPD-91 x PGCP-1 }\end{array}$ & $\begin{array}{l}-6.556 \\
-5.389 \\
-5.333 \\
-5.333 \\
-4.889 \\
-4.722 \\
-4.556 \\
-2.722\end{array}$ \\
\hline Plant height at maturity & $\begin{array}{l}\mathrm{HC}-08-02 \\
\text { CPD-91 }\end{array}$ & $\begin{array}{c}13.882 \\
1.755\end{array}$ & 11 & $\begin{array}{l}\text { JOB-129 x CP-105 } \\
\text { HC-08-02 x PGCP-1 } \\
\text { HC-08-02 x GC-06-01 } \\
\text { CPD-91 x JOB-129 } \\
\text { GC-06-01 x JOB-129 } \\
\text { CPD-91 x PGCP-1 } \\
\text { HC-08-02 x JOB-129 } \\
\text { GC- x JOB-129 } \\
\text { PGCP-1 x GC-06-01 } \\
\text { CPD-91 x CP-105 } \\
\text { GC-3 x CPD-91 }\end{array}$ & $\begin{array}{l}14.028 \\
11.875 \\
11.111 \\
7.647 \\
6.584 \\
5.672 \\
5.461 \\
5.428 \\
5.028 \\
4.972 \\
3.057\end{array}$ \\
\hline $\begin{array}{l}\text { No. of branches per } \\
\text { plant }\end{array}$ & $\begin{array}{l}\mathrm{HC}-08-02 \\
\mathrm{CP}-105 \\
\text { GC-3 }\end{array}$ & $\begin{array}{l}0.586 \\
0.330 \\
0.263\end{array}$ & 4 & $\begin{array}{l}\text { JOB-129 x CP-105 } \\
\text { GC-3 x CPD-91 } \\
\text { GC-3 x HC-08-02 } \\
\text { HC-08-02 x PGCP-1 }\end{array}$ & $\begin{array}{l}0.933 \\
0.844 \\
0.722 \\
0.644\end{array}$ \\
\hline No. of pods per plant & $\begin{array}{l}\text { GC-3 } \\
\text { CP-105 }\end{array}$ & $\begin{array}{l}3.317 \\
2.206\end{array}$ & 2 & $\begin{array}{l}\text { GC-3 x HC-08-02 } \\
\text { JOB-129 x CP-105 }\end{array}$ & $\begin{array}{l}3.331 \\
3.053\end{array}$ \\
\hline Pod length & $\begin{array}{l}\text { GC-06-01 } \\
\text { PGCP-1 }\end{array}$ & $\begin{array}{l}0.472 \\
0.390\end{array}$ & 3 & $\begin{array}{l}\text { GC-3 x JOB-129 } \\
\text { HC-08-02 x PGCP-1 } \\
\text { CPD-91 x GC-06-01 }\end{array}$ & $\begin{array}{l}1.819 \\
1.392 \\
1.041\end{array}$ \\
\hline
\end{tabular}


GC-3 x JOB-129

GC-3 x PGCP-1

HC-08-02 x CP-105

HC-08-02 x PGCP-1

GC-06-01 x JOB-129

GC-3 x CP-105

100 Seed weight

Seed yield per plant

GC-3

CP-105

2.206

0.801

Harvest index

Protein content

PGCP-1

JOB-129

0.849

0.535
4

GC-3 x CPD-91

PGCP-1 x JOB-129

PGCP-1 x CP-105

GC-3 x HC-08-02

GC-3 x HC-08-02

GC-06-01 x JOB-129

HC-08-02 x PGCP-1

JOB-129 x CP-105

GC-3 x CP-105

GC-3 x CPD-91

GC-3 x JOB-129

GC-06-01 x CP-105

GC-3 x HC-08-02

CPD-91 x PGCP-1

GC-3 x PGCP-1

CPD-91 x HC-08-02

PGCP-1 x CP-105

CPD-91 x CP-105

PGCP-1 x JOB-129

HC-08-02 x JOB-129

PGCP-1 x GC-06-01

GC-3 x JOB-129

HC-08-02 x GC-06-01

GC-3 x HC-08-02

GC-3 x CPD-91

$$
\begin{aligned}
& 2.024 \\
& 1.820 \\
& 1.813 \\
& 1.354 \\
& 1.286 \\
& 1.044 \\
& 1.569 \\
& 1.477 \\
& 1.082 \\
& 1.047 \\
& 4.714 \\
& 3.321 \\
& 2.535 \\
& 2.240 \\
& 2.198 \\
& 1.882 \\
& 1.825 \\
& 1.599 \\
& 2.732 \\
& 1.661 \\
& 1.449 \\
& 1.144 \\
& 7.722 \\
& 5.244 \\
& 5.033 \\
& 2.723 \\
& 2.668 \\
& 2.637 \\
& 2.338 \\
& 2.136 \\
& 2.103
\end{aligned}
$$


The present investigation also confirmed that some of the parents having significant positive gca effects for seed yield per plant also showed positive gca effects for one or more of yield contributing traits and can also be concluded that parents, who exhibited high per se performance, also displayed good general combining ability effects. Hence, per se performance may be used effectively for the selection of parents.

Similar results of positive association of per se performance and general combining ability and its usefulness in selection of the parents were also reported by Mannivannan and Sekar (2005). The parents showing high general combining ability with gca effects and the hybrids showing best specific combinations with sca effects for different characters were presented in table 6 . The hybrids, GC-3 x HC-08-02,GC-06-01 x JOB-129 and HC-08-02 x PGCP-1showed the significant positive sca effect for seed yield per plant. The hybrids, GC-3 x JOB129 and GC-3 x PGCP-1 exhibited highest significant positive sca effect for number of seeds per pod. While hybrids GC-3 x CPD91 and PGCP-1 X JOB-129revealed significant positive sca effect for 100 seed weight and hybrids PGCP-1 x CP-105,CPD$91 \times$ CP-105 and PGCP-1 x JOB-129 recorded maximum significant positive sca effect for the character protein content. These results were in accordance with Mannivannan and Sekar (2005), Hira Lal et al., (2009) and Ayo-Vaughan (2013) for number of pods per plant and 100 seed weight.

The best combinations for seed yield per plant viz., GC-3 x HC-08-02, GC-06-01 x JOB-129, HC- 08-02 x PGCP-1, JOB-129 x CP-105 and GC-3 x CP-105 involved one or both the parents having either good or average or poor general combiner for seed yield, and possessed high gca effects (parent) and also exhibited significant sca effects (crosses) in desirable directions for one or more yield contributing attributes. To cite an example, the hybrids viz., GC-3 x HC-08-02, GC-06-01 x JOB-129 and HC08-02 xPGCP-1 displayed significant sca effects for six, three and six characters, respectively in desirable direction including seed yield per plant (Table 6). The relationship between gca and sca effects confirmed that significant and desirable sca effects can occur in any group of gca of parents indicating the presence of higher order interactions in the expression of these traits and in addition to this, sca effects occurred because it all depends upon how well genes from two parents interact. The occurrence of high sca effects in good $\mathrm{x}$ good group might be due to cumulative effect of high combining loci and no mutual cancelation of gene effects between high general combining loci. On the other hand high sca effects in good $x$ average or average $\mathrm{x}$ good, average $\mathrm{x}$ poor or poor $\mathrm{x}$ average group might be due to complementation of low, good and poor or average combining loci. Therefore, based on outstanding performance of selective parents and crosses in present study, can be concluded that desirable parents could be used as donors to get high yield and the selective crosses were identified as outstanding for seed yield and its components traits due to possessing high sca effect for seed yield may further be utilized in future under breeding programme.

\section{Acknowledgements}

Authors are grateful to the Mahatma Phule Krishi Vidyapeeth, Rahuri (India) for providing the financial help to carry out this work and also to the Professor of Botany, College of Agriculture, Dhule for his keen interest and facilities provided for the present study. 


\section{References}

Anonymous. 2012. FAO, FAOSTAT.

Ayo-Vaughan, Monininuola Adefolake, Ariyo, Omolayo Johnson and Alake, Christopher Olusanya. 2013.

Chaudhari, S.B., Naik, M.R., Patil, S.S. and Patel, J.D. 2013. Combining ability for pod Yield an seed protein in cowpea (Vigna unguiculata (L.) Walp) over environments. Biosci., 6: 395-398.

Combining ability and genetic components for pod and seed traits in cow pealines. Italian J. Agron., 8: 73-78.

Davis, D.W., Oelke, E.A., Oplinger, J., Doll J.D., Hansan, C. V. and Putnam, D. H. 2000. Alternative Field Crops Manual, pp. 1-9.

Ehlers, J.D. and Hall, A.E. 1997.Cowpea (Vigna unguiculata (L.)Walp.) Field Crop Res., 53: 187-204.

Griffing, B., 1956. Concept of general and specific combining ability in relation to diallel Crossing system. Aust. J. Biol. Sci., 9: 463-493.

HiraLal, Singh, A. P., Matura, Rai, Bhardwaj, D. R., Rai, N. and Vishwa Nath. 2009. Combining ability of quantitative characters in cowpea (Vigna unguiculata (L.) Walp). Veg. Sci. 36: 265-267.

http//www.faostat.fao.org.

Huja, S.L. and Dhayal, L.S. 2007. Combining ability estimates for yield and fiber quality traits in $4 \times 13$ line $\mathrm{x}$ tester crosses of Gossypium hirsutum. Euphytica, 153: 8798.

Kadam, Y.R., Patel, A.I., Patel, J.M., Chaudhari, P.P. and More, S.J. 2013.
Combining Ability study in vegetable cowpea (Vigna unguiculata (L.) Walp). Crop Res., Hissar. 45: 196-201.

Kumar, D. and Sangwan V.P. 2005. Combining ability studies for yield and architectural traits in cowpea (Vigna unguiculata (L.) Walp). Ann. of Bio., 21: 47-49.

Manivannan, R. and Sekar, K. 2005. Combining ability for yield and different quality traits in vegetable cowpea (Vigna unguiculata (L.) Walp.) Indian J. Hort., 6.

Marciniak, K., Kaczmarek, Z., Adamski, T. and surma, M. 2003. The anthercultureresponse of Triticale line $\mathrm{x}$ tester proginies. Cell Mol. Biol. Lett., 8: 343351.

Meena Ramesh, Pithia, M. S, Savaliya, J.J. and Pansuriya, A.G. 2009. Heterosis in vegetable cowpea (Vigna unguiculata (L) Walp.), Crop Improv., 36: 47-50.

Sprague, G.P. and Tatum, L.A. 1942.General vs. specific combining ability in single crosses of corn. J. Amer. Soc. Agron., 34: 923-932.

Ushakumari, R., Vairam, N., Anandakumar, R. and Malini, N. 2010. Studies on hybrid Vigour and combining ability for seed yield and contributing characters in cowpea (Vigna unguiculata). Electronic J. Plant Breeding, 1: 940-947.

Valarmathi, G., Surendran, C. and Muthiah, A.R. 2007. Studies on combining ability for yield and yield traits in inter subspecies of cowpea (Vigna unguiculata SSP. Unguiculata and Vigna unguiculata SSP. Sesquipedalis) Legume. Res., 30: 173 -179 .

\section{How to cite this article:}

Raut, D.M., A.B. Tamnar, S.V. Burungale and Badhe, P.L. 2017. Half Diallel Analysis in Cowpea [Vignaunguiculata (L.)Walp.]. Int.J.Curr.Microbiol.App.Sci. 6(7): 1807-1819. doi: https://doi.org/10.20546/ijcmas.2017.607.218 